\title{
Agricultural Sector in District Anantnag of J\&K A Shift from Producer to Consumer
}

\author{
Dr.Syed Damsaz Ali Andrabi \\ College Teacher, History, \\ Department of Higher Education, J\& K
}

\author{
Dr. Mohd. Yousuf Bhat, \\ Assistant Professor, Political Science, \\ Department of Higher Education J \& K
}

\begin{abstract}
The district Anantnag right from its inception is known as the major supplier of agricultural produce, because major portion of population of the district comprised of rural areas and were involved in agricultural activities as their main source of income. The non-seriousness of authorities has forced the agricultural section of society to look for some other options. Within a short span of time rice and maize the major crops were replaced by fruit and willow plantation at a larger scale. This shift to new plantation has proved very beneficial as compared to other crops. Kashmiri apple has become very popular throughout the country. Its high demand has really opened the new ways of development. Similarly the willow cricket bats of Kashmir have earned the world reputation. The new module to a certain extent has revived the trade links of Kashmir. One the one hand it has proved to be fruitful business but on the other it has started to bring miseries in shortage of food and very soon people have to face the severe crisis of food. The food at present is procured from other parts of country. During earlier times people were producers, but at present they have become consumers. The authorities have never tried to improve the quality of main crops of valley that resulted in its decline.
\end{abstract}

KEYWORD: Agriculture, Economy, Rice, Maize, Shift, Horticulture, Technology

\section{INTRODUCTION}

The major crops of District Anantnag are rice, maize, wheat, mustard. Almost 95\% portion of population are living in rural areas mostly depend on these crops. But due to changing cropping pattern the production of some crops increased whereas of other crops decreased. From the last three decades the cultivation of rice and maize decreased considerably whereas the cultivation of oilseeds, oats, etc. increased. The decrease of rice and maize has created chronic and severe problems not only to the people who in no case are linked with cultivation, but even to the cultivators themselves, because rice as staple and the only food for the people of district. Although shift from agricultural activities to horticultural activities had produced gainful employment to sizable section of population, this resulted in decline in production of rice and maize. Agricultural work accommodates majority of the population as it doesn't require any major skill while as Horticulture requires skill based workers. This occupational shift also bought redundancy among rural populace as a matter of shift of occupation and forced larger section of people who were associated with agricultural sector to shift to other parts of the country in search of livelihood. Due to the paucity of rice and maize, the people of district have to get the same from other states at a higher cost, which causes loss of economy and it leads to poverty of people.

The importance of agriculture in the development of nation was recognized even before the publication of wealth of nations. The leading classical writers such as Richard Cautillon, Turgot and Francis Quesnay in fact over emphasized the role of agriculture. The economists like, Schultz, Wilcox and others have clearly highlighted the role of agriculture by referring it to the interdependence of the various sectors of the economy. Historically speaking the process of economic development has been accompanied by the growth of industry and agriculture. In the short run the development of these two leading sectors has been competitive in the sense that both compete for the scarce resource particularly, capital. It is recognized fact that both in the process of transformation of a predominantly agrarian system into a predominantly industrial system, the share of agriculture in the national income have been registering a decline trend over the years. Despite this trend contributing towards 
the process of transformation and interactions as well as interdependencies between agriculture and industry is well recognized. Agriculture must provide food for the growing population and for the increasing demand ensuring from higher per capita income. It must also provide a surplus for export to finance the capital equipment and other imports required for developmental purposes. If it fails to accomplish these objectives it can lead to higher food prices, wage costs, increased import of food, and increased dependence on imported inputs.

Agriculture is considered as a strong option and fundamental instrument for spurring growth and sustainable development, poverty reduction and enhancing food security in developing countries like India. Although agriculture occupies a shrinking share of India's national economy, achieving rapid growth in agriculture sector remains a nationwide major policy concern. The contribution of agriculture to India's gross domestic product (GDP) fell from 40\% in $1980 / 81$ to $13.7 \%$ in $2012-13$ (CSO, GOI 2012-13). However, more than $70 \%$ of India's population lives in rural areas, and three-fourths of them depend on agriculture and allied activities for their livelihoods. Furthermore, the agricultural sector is the main source of employment in India, comprising $52 \%$ of the country's labour force in 2011/2012.

In case of Jammu and Kashmir State, the outer plains of Jammu and the fertile valley of Kashmir are intensively cultivable, while dry plateau of Ladakh and lofty mountainous areas of state are almost uncultivable. Same is the case with district Anantnag. Cultivation of crops is dominant occupation of the people in the district. Agricultural activities have added to the income of people. In the district conventional practices were followed by the farmers and consequently yield per unit was very low up to the late forties. After the introduction of land reforms act in 1948 (big land estates act or abolition of Jagirdari system) the ownership of land was transferred to landless tillers who were till then growing under the just exploitive system of share cropping and arbitrary ejectments and vigorous drive started under more food campaign to make the state self-sufficient in food. The geographical and reporting area according to revenue records of district Anantnag is, 1,07,60,000 Kanals and,43,60,000 Kanals respectively. The percentage of new area sown in district Anantnag is, $57 \%$ of reporting area as compared to, $62 \%$ of Kashmir valley and $30 \%$ of the state. The net area sown in district is, 25,80,000 Kanals. Rice and maize are the principal crops and accounts for an area of $55.8 \%$ and, $27 \%$ respectively of total sown area. In district, $66.5 \%$ of total sown area is irrigated by different sources. Cropping pattern of district reveals the proportion area under different crops, the rotation of crops keeps on changing from time to time due to various factors such as increase or decrease of market value of crops, rejection of traditional varieties and other high yield varieties, contraction of land, climatic factors etc.

In district paddy, maize, wheat and oilseeds are the principle crops and rice is the staple food for the people. The area in Kanals under rice cultivation from, 1965-1998, is shown in table.

\section{Area under Rice cultivation in Kanals}

\begin{tabular}{|c|c|c|c|c|c|c|}
\hline 1965 & 1970 & 1975 & 1980 & 1985 & 1990 & 1998 \\
\hline 1131060 & 12430000 & 1140000 & 1129400 & 828880 & 819790 & 814416 \\
\hline
\end{tabular}

Source: Digest Statistics, 1965-85, Revenue Department of Anantnag, 1990-98.

It is apparent from the table that the cultivation of rice increased up to 1970 only. From then onwards the agricultural produce of rice declined too much. The data of 1998, indicates that there was only, 814416 Kanals of land under paddy/rice cultivation, i e. 428684 Kanals of paddy cultivated land was diverted to other crops particularly to fruit production and popular willow plantation during, 1970-1998.It has various reasons, such as the market value of fruits and wood of popular willow is very high as compared to rice and other crops. Commercially paddy, maize and other crops cannot act as a match for fruit production and willow plantation. Not only that another reason for diversion of paddy crops to other crops is weather. 
Nature has compelled the paddy cultivators of Anantnag district particularly of plain areas to divert their paddy crops. Uncertain rains and floods badly affected paddy, maize and other crops. During 199095 floods affect $80 \%$ of crops in these areas during these years. So the cultivators were compelled to plant popular and willow plants. The diversion of paddy crops creates not only the food problem for the population of district, but also affected the livestock population. Agriculture eventually also became relatively less remunerative profession due to low yields and its impact was direct on new younger generation who shed away from this sector towards urban centric vocations.

The livestock population of the district from, 1972-82 of district is shown in table.

\section{Livestock population in lakhs}

\begin{tabular}{|c|c|c|c|c|}
\hline Year & Cattle & Buffaloes & Sheep & Goats \\
\hline 1972 & 3.93 & 0.07 & 2.80 & 0.25 \\
\hline 1982 & 2.68 & 0.07 & 1.59 & 0.18 \\
\hline
\end{tabular}

Source: Livestock census report, 1972-82

The data indicates that cattle rearing are more as compared to other animals in district. But the above table also indicates that the number of cattle decreased from, 3.933, lakhs to 2.68 , lakhs. The reason is that in district during the winter the cattle are feed with socked paddy grass and husk of rice, as during winter there is no fresh green grass in whole of Kashmir. Due to the contraction of paddy cultivation, the production of paddy grass and husk also decreased which forced cattle rears to decrease their number of cattle. Same is the case with other animals like goat, sheep etc.

\section{Area under maize cultivation in Kanals}

\begin{tabular}{|c|c|c|c|c|c|c|}
\hline 1965 & 1970 & 1975 & 1980 & 1985 & 1990 & 1998 \\
\hline 833666 & 800321 & 700000 & 527200 & 440400 & 436500 & 432712 \\
\hline
\end{tabular}

Source: Digest of Statistics, 1965-85, J\&K Government. Revenue Department of Anantnag, 1990-98.

It is evident from the table that the cultivation of maize decreased from, 1965-98. In, 1965, the 833666, Kanals of land were under maize cultivation in district. But in, 1998, only, 432712, Kanals of land remained under the cultivation of maize, I.e, 1965-98,400954 Kanals of maize crops were diverted into other crops.

\section{Area under Pulses in Kanals}

\begin{tabular}{|c|c|c|c|c|c|c|}
\hline 1965 & 1970 & 1975 & 1980 & 1985 & 1990 & 1998 \\
\hline 112333 & 102100 & 100000 & 87900 & 69000 & 48700 & 27376 \\
\hline
\end{tabular}

Source: Digest of Statistics, 1965-85 J\&K Government. Revenue Department of Anantnag, 1990-98. 
The diversion of pulse cultivation is more as compared to other crops. The reason for diversion of pulse crops is that the production of pulses is very low.

The importance that agriculture commands in the economy of district can be judged from the fact that primary occupation of people is agriculture and its allied activities. A major part of income is generated by this sector. The economy of Anantnag is deep rooted in agriculture and is rather the pivot round which all its economic activities revolve because, it still continues mostly as an agrarian district. Excessive dependence on agriculture and lack of diversified economic structure stand as the main feature of economy. These characteristics represent the relative backwardness of people. No doubt the production of crops increased from sixties due to green revolution. Since the diversified cropping pattern left lesser area for cultivation of paddy, maize and other major crops. So the production got adversely affected and the cultivators who entirely depend on this cultivation became economically weak. Some of the reasons for the contraction of land are due to increasing population new buildings, factories and industries are constructed in the cropping fields. These constructions cover a large portion of land every year. The cropping areas became contracted and it directly effects on its production. Another cause for diversion of cropping land is the constant threat of floods faced by the people of plain areas. Nature has forced the farmers of these plain areas to look for other alternatives of income and subsistence. At present much of the land is covered by the plants. The plantation becomes very common because of the negative approach of authorities. Draught and other uncertain factors too contributed a lot towards the diversion of cropping land. In summer season there is shortage of constant water supply for paddy fields. Besides the supply could be replenished by means of lift system but that too is not available. So the fields are dependent on rains which are always uncertain. Due to draughts the farmers get compelled to change their cropping pattern. Another important factor for the contraction of cropping land is the increasing market value of popular and willow plants. Wood of willow is used for the formation of cricket bats and fruit boxes. Wheres, popular trees are used in manufacturing of plywood. Plantation has proved highly payable instead of paddy and other major crops. This also affected the cropping pattern of Anantnag district.

\section{Area under Fruits, 1965-98 in Kanals}

\begin{tabular}{|c|c|c|c|c|c|c|}
\hline 1965 & 1970 & 1975 & 1980 & 1985 & 1990 & 1998 \\
\hline $\mathbf{3 0 4 0 0}$ & 64000 & 100000 & 127000 & 140600 & 167670 & 176640 \\
\hline
\end{tabular}

Source: Horticulture department, Government of Jammu and Kashmir. Revenue Department of District Anantnag, 1990-98.

Horticulture in recent years has emerged as an important sector in Anantnag district. Fruit production particularly apple production is increasing not only in district Anantnag but throughout the valley of Kashmir. A large portion of cropping land is being diverted to fruit production every year because of high market consumption and value. From, 1965-98, 146240, Kanals of rice, maize and other crops were diverted to fruit cultivation. Commercially the rice, maize and other crops cannot stand as a match for fruit cultivation. Fruit cultivation requires less irrigation than rice cultivation and is less affected by the floods as compared to rice and maize. So this is another factor which is responsible for changing cropping pattern and contraction of major cropping land.

The cultivation of cropping land directly affects the productivity and production which results in mass poverty of people. Due to the non-availability of rice the people have to get rice from other states which costs higher and acts as a drain of rich economic resources. Due to non-availability of food, the demand increased and result was increase in prices, secondly, decrease in the production of rice and maize has affected the poultry farms which were dependent on food grains also ameliorated problem of poverty as 
this was sector which was providing employment to a large section of population.

Third important reason in decline of agriculture sector is the conversion of agricultural land for commercial purposes and this threat continues to be unabated in Jammu and Kashmir in absence of any monitoring and action by the state government. One important reason for this is the skyrocketing land prices which are likely to convert the entire Kashmir countryside into a "monster of concrete," In south Kashmir, which includes district Anantnag once known as rice bowl of Kashmir. Agriculture land is shrinking at an alarming rate as the Government continues to be a mere spectator to this onslaught. As one could see swathes of Abi-Awal land-strictly to be used for agricultural purposes is being turned into concrete jungles with shopping malls, business units and residential buildings coming up.

Although late the state government has passed a law in 2010 The Jammu and Kashmir Prohibition on Conversion of Agricultural Land for non- agricultural Purposes Act,2010 which clearly says that no person shall convert or put to use agricultural land for any non-agricultural purpose excepting with the written permission granted under section 7 .

It has been found that people first convert paddy land into non-paddy by sowing plant nurseries, vegetable fields and orchards. And after few years the same practice of agriculture is being abandoned and construction is carried without any trouble. To avoid Government wrath the farmers convert paddy fields into plant nurseries and after that the same piece of land is used for construction and other purposes, The Horticulture Department in its recent report mentioned that the area under the apple crop has increased by 3378 hectares in 2013-14. According to the report, the area covered under apple crop was 1 , 40,156 hectares which has increased to $1,43,534$ hectares in 2013-14.

Despite High Court's directions to Government for imposing a blanket ban on raising constructions in paddy land, and in brazen violation of Section, 133 of Land Revenue Act, the official reports revealed that paddy land was increasingly being used for residential and commercial purposes shrinking the land from 1.6 lakh hectares to 1.4 lakh Kanals from the last 7 years. The Economic Survey Report also portrays a grim picture of conversion of agricultural land, saying it is happening at an alarming rate and leading to further dependence of food on imports from outside the state. As per the report, the arable land in J\&K has shrunk from 0.14 hectare per-person in 1981 to 0.08 hectare per-person in 2001 and further to 0.06 hectare per-person in 2012. Factors like small holdings create problems in farm mechanization operations and make farming non-remunerative. Apart from population growth, urbanization process leads to shrinkage in per capita arable land. As per Agriculture department figures, two lakh kanals of agriculture land of the net sown or cultivated area of 3.5 lakh hectares has been converted for commercial and other purposes in Kashmir. The loss of agricultural land to urbanisation has raised alarm bells but solutions have been elusive.

The ESR states the share of agriculture and allied activities to GSDP has scaled down from $56.64 \%$ in $1970-71$ to $32.58 \%$ in $2000-01$ then to $28.06 \%$ in $2004-05$, and posted only $17.49 \%$ contribution as per advance estimates for 2014-15 at constant (2004-05) prices.

In April 2012, the J\&K High Court passed directions against the misuse of agricultural land on a related Public Interest Litigation filed by a non-governmental organization. It directed all deputy commissioners to ensure the provisions of the Jammu and Kashmir Agrarian Act, and the Jammu and Kashmir Land Revenue Act, are to be implemented to stop the conversion of agricultural land.

Fourthly, in agricultural sector traditional mode of farming was in practice but with passage of time with the new technology adoption there is increase in the production and generates employment for a particular group of population, but it has adversely affected labour employment in agricultural sector. Technology has been classified into divisible and mechanized technology. Under divisible technology include irrigation, high yielding varieties of seeds, weedicides, pesticides, small tools and implements. Increasing use of technology helps in augmenting the employment and also contributes to the reduction in income inequalities. But mechanical inputs such as a big tractor, harvest combines, threshers and similar other inputs have adversely affected labour employment in agriculture. The bullock has considerably gone down owing to the use of new farm technology. 
Fifthly another problem is lack of education and ignorance of farmers particularly living in hilly areas of district. They use traditional varieties of seeds and do not take the benefit of fertilizers, pesticides and weedicides. Water resources are available in these areas but there are not channels to get water from sources to the fields. So they mostly depend on rain water which is uncertain and is not fit for their fields. A large portion of land in those areas remains uncultivated. In sloppy areas the fields are in helix order. There is much loss of fertilizers from these fields, which is one cause of low production in these areas of district.

\section{CONCLUSION}

The cropping pattern of different major crops reveals that there is considerable diversion of land. The same has given birth to number of problems pertaining to farmers, such as paucity of food and its negative fallout on livestock population. Uncontrolled urbanization has put a negative impact on agricultural land use which needs to be addressed and reassessed by the policy makers. More and more agricultural land got converted in non-agricultural use particularly construction of new housing colonies which needs a positive attention from all concerned quarters including the active participation of farmers. Strict laws have been promulgated involving punitive action for any violation, particularly in respect of more productive land (Abi-awal etc). Latest technology including new quality of seeds coupled with organic farming needs to be adopted so as to make agriculture a profitable and attractive sector. This needs certain innovative measures especially followed by the European countries. Producers should feel it as viable economic and sustainable growth option which will arrest abandonment of younger generation from this lucrative occupation. State has to make certain important strides in this regard such as providing healthy availability of agricultural produce at reasonable prices. No doubt horticulture is a profitable option but it is not cup of everybody as it needs, land, skill, money etc. There is need to synergies both agriculture and horticulture sectors which will not only provide sustenance but as well as growth option for common masses of the district.

\section{REFERENCES}

1) Bamzai,Anand Koul,Geography of Jammu and Kashmir,Calcutta,1913.

2) Davis,T.S,Agricultural fundamentalism, reproduced in agricultural policy, edited by, o.e.Jesness, 1949.

3) Pithawalla Maneck,Introduction of Kashmir,its Geology and Geography,Pakistan, 1953.

4) Christensen,R.P,Population growth and agricultural development, Agricultural economic research, vol, 18,1966.

5) Basu, D. N, Ragh Roy and etal, Impact of agriculture department on demographic behavior, Delhi, 1979.

6) Sadhu and Singh, Fundamentals of agricultural economics, Delhi, 1983.

7) Deb K,Rural development in India since Independence,Delhi, 1986.

8) Lawrence Walter,Valley of Kashmir,Srinagar,2000.

9) Statistical handbook of district Pulwama,200809,Panning and development department.

10) Census report of Jammu and Kashmir,2010-11.

11) Hussain Majid, Geography of Jammu and Kashmir, Srinagar,2000.

12) Raoof Ahmad Lone, Vinod Sen,Horticulture Sector in Jammu and Kashmir Economy, European Academic Research ,Vol. II, Issue 2/ May 2014

13) Govt silent as paddy land shrinks at alarming rate, Daily Excelsior, 14th May 2014

14) http://www.Kashmirlife.net/economic-survey2014-15-a-general-review-78263/.

15) Mukeet Akmali, In JK. agricultural land conversion continues under government nose, Greater Kashmir, October 27, 2015

16) Would Kashmir's autumnal grandeur be lost to urbanization greed?, India TV News Desk, $10 \mathrm{Sep}$ 2015.

17) S.C.Raychoudhary,Social Cultural and economic History of India,modern times,Delhi,2005. 